Published in Applied Catalysis A: General, 482 (2014) 116-126

doi:10.1016/j.apcata.2014.05.035 http://www.elsevier.com/

\title{
Efficient retention of laccase by non-covalent immobilization on amino-functionalized ordered mesoporous silica
}

\author{
V. Gascón, C. Márquez-Álvarez, R. M. Blanco*
}

Molecular Sieves Group. Institute of Catalysis and Petroleum Chemistry (ICP-CSIC)

C/ Marie Curie, 2. Cantoblanco 28049. Madrid. Spain.

*Corresponding author: E-mail address: rmblanco@icp.csic.es (Rosa M. Blanco)

Phone +34 915854785 , Fax: +34 915854760 


\section{ABSTRACT}

The present work aims to be a step forward in the synthesis of siliceous ordered mesoporous materials (OMM) as tailor made matrices to optimize the immobilization and stabilization of enzymes. Based on a classic non-covalent adsorption by electrostatic interactions we have developed the syntheses of materials especially designed for this enzyme, in order to optimize the properties of the final biocatalyst. Siliceous materials with a hexagonal arrangement of parallel mesoporous channels (SBA-15 type of structure) have been synthesized, whose pore diameter has been tuned according to the molecular dimensions of laccase. The synthesis conditions used allowed to obtain pore sizes large enough to permit laccase entrance and diffusion through the pore channels. Diffusion of the enzyme is crucial to obtain high immobilization yield since most of the surface area of the particles is the internal surface of the pores. A poor diffusion would involve retention of enzyme molecules in the pore mouths preventing new ones to access the channel and leading to a low enzyme loading of the catalyst. A micelle swelling agent has been used to expand the supramolecular aggregates that generate the pore architecture of SBA-15 silica. The surfaces of the supports were functionalized with amino groups aiming to strengthen electrostatic interactions between support and enzyme at a suitable $\mathrm{pH}$. Two strategies of surface functionalization of the large-pore ordered mesoporous silica materials were followed: 1) anchoring of an amino-functional alkoxysilane on mesoporous silica and 2) direct co-condensation of a silicon alkoxide and an amino-functional alkoxysilane to obtain the functionalized material in one step. The possibility to prepare carriers where each characteristic has been separately studied and optimized has allowed to obtain biocatalysts with optimal properties. Enzyme loading up to $187 \mathrm{mg}$ per gram of catalyst and high activities were achieved with the amino-functionalized large-pore supports. 
Furthermore, immobilization improved enzyme stability in ethanol. Strong binding forces were capable of housing and retaining the enzyme irreversibly, fully preventing leaching in aqueous medium. Through the careful design of the support material, the biocatalysts obtained share the advantages of enzyme-support covalent attachment regarding absence of leaching and stability, while avoiding drawbacks like loss of activity and enabling the reuse of the support

KEYWORDS. Biocatalysts. Enzyme immobilization. Laccase. Large pore. Ordered Mesoporous Materials.

\section{INTRODUCTION}

The field of ordered mesoporous materials (OMMs) has been progressively growing in the last two decades, and a wide variety of new different types of materials and structures have been obtained [1]. These mesostructured materials have rapidly acquired significant attention in the field of materials science and in many areas of chemistry and biotechnology [2-5]. Using cationic surfactants to template the pore architecture, mesoporous silica materials with well-ordered pore networks were first obtained by Mobil Corporation in $1991[6,7]$. The possibility to obtain silica with different pore network topologies and the ability to tailor pore size boosted the rapid growth of research activity in this field of materials science. Pore size control in OMMs can be achieved by modifying surfactant type and chain length or by adding a swelling agent [8]. Silica with a pore size of approximately $3 \mathrm{~nm}$ can be made using cationic surfactants, with reasonably short alkyl chains [6]. By replacing the cationic head group by a larger non-ionic group, the size of the surfactant micelles can be increased and materials with pore sizes in the range of 5-6 nm are obtained [9]. Even larger surfactants 
like polyethyleneoxide-polypropyleneoxide-polyethyleneoxide triblock copolymers can produce materials with pore sizes of $7 \mathrm{~nm}$ and higher such as SBA-15 silica, which possesses a two-dimensional hexagonal structure of cylindrical mesopores [10]. These pore diameters are however not sufficient for the immobilization of large enzymes with high molecular weight. On the other hand, the synthesis of mesoporous silica with large pore size tends to lead to less ordered structures. Making use of this approach, the size of mesopores is limited by the dimensions of the micelle templates, and well-ordered SBA-15 materials with pore size up to $10 \mathrm{~nm}$ have been obtained [11]. Other mesostructures, named foam-like (MCF) or worm-like mesoporous molecular sieves, have also been reported showing disordered mesoporous structures with a pore size up to $10 \mathrm{~nm}$, (HMS $\left(\mathrm{D}_{\mathrm{p}}=2-10 \mathrm{~nm}[12]\right.$; MSU-J $\left(\mathrm{D}_{\mathrm{p}}=2.5-10 \mathrm{~nm}[13-15]\right)$.

The addition of swelling agents which are dissolved inside the hydrophobic regions of the surfactant micelles allows to further increase the pore diameter of the solid $[9,16]$. Hydrophobic swelling agents such as substituted aromatic hydrocarbons (1,3,5trimethylbenzene, 1,3,5-triisopropylbenzene) or other organic compounds like alcohols (butanol, pentanol, hexanol), aliphatic hydrocarbons (dodecane), tertiary amines, poly(propylene glycol), etc., have been used to expand the pore size of SBA-15 silica up to $12-15 \mathrm{~nm}[8,17,18]$. However, the pore diameter of these materials has to be primarily controlled through the selection of the initial synthesis temperature, and further adjusted through the selection of the hydrothermal treatment temperature and time, as well as the type and amount of the swelling agent [18]. Otherwise, an increase in the amount of the swelling agent causes the formation of a different structure, called a mesocellular foam (foamlike), which is poorly ordered or disordered and features spherical mesopores of large diameter $(20-40 \mathrm{~nm})[19,20]$. In most cases it results in disordered mesostructures with the loss of the 2D hexagonal ordering [4]. 
Mesostructured materials offer versatile features, such as high specific surface area, large specific pore volume, narrow pore size distribution, mesopores interconnected by micropores, tunable chemical properties and high chemical and mechanical stability. These unique properties have been previously reported in our group for lipases [21-23]. The aim on this work is to go further in the synthesis of OMM with larger pore sizes which open new possibilities for immobilization of molecules too large to fit into the pores of standard OMM. This is the case of laccase from Myceliophthora thermophila $(M t \mathrm{~L})$, an enzyme with larger dimensions than lipase.

Laccases (benzenediol:oxygen oxidoreductase, E.C. 1.10.3.2) belong to the group of blue multicopper oxidases, an important class of enzymes found in many organisms, including plants, insects, fungi and bacteria [24-27]. These enzymes catalyse the reduction of molecular oxygen to water by oxidation of various phenolic compounds. The fact that they only require molecular oxygen for catalysis makes them suitable for different applications [26].

In last years, laccases have been used for many different biotechnological processes, such as pulp delignification, oxidation of organic pollutants, textile and petrochemical industries [28], development of biosensors [29], or wine and beverage stabilization [3034] among other uses [33, 35-37]. Some attempts to use laccase in wine and beer industries have been done $[30,33,34,38]$ and this seems to be an interesting application to study. However, the use of soluble laccase is not allowed in these industries, which highlights the relevance of immobilized enzyme with optimized properties.

Furthermore, the industrial application of free laccases is limited since their stability and catalytic activity are considerably affected by a variety of environmental conditions [35]. In fact, immobilization allows easy separation from the reaction medium by 
simple filtration, potential reuse of the biocatalyst and sometimes more resistance of the enzyme to a thermal or chemical inactivation.

In this work, a classic enzyme immobilization method on amino-containing surfaces is used. Particularly, the design of ordered mesoporous materials with the exact pore size required by laccase, and the synthesis conditions of this kind of materials also containing amino groups are studied and presented. Pore size is maybe the most relevant parameter; it must be wide enough to enable the enzyme to enter and diffuse along the channels, leaving room for new molecules to enter as well. In the opposite situation, if the enzyme does not diffuse, then the molecules would be stacked in the pore mouths, acting as a stopper and preventing new laccase molecules to enter the pore. As a consequence, most of the inner pore surface would not be occupied by enzyme and the immobilization yield would be low.

Immobilization of laccases on OMM have been reported in the literature with varying degrees of success, mainly due to denaturation processes and restricted diffusion of the substrate [40-42]. We have chosen electrostatic interactions as the driving forces for laccase immobilization. $M t \mathrm{~L}$ has a low isoelectric point, so we propose in this work the functionalization of the siliceous supports with high $\mathrm{pK}_{a}$ groups (amine) $[4,43]$ to interact with negative charges of the enzyme [44].

Many research efforts have focused on surface functionalization of mesoporous silica materials with organic groups (such as amine) by the direct incorporation of these functionalities through co-condensation of siloxane and organosiloxane precursors [45, 46] or by post-synthesis grafting of organic groups onto the surface of the mesoporous silica [2, 47]. The presence of these groups in mesoporous materials additionally decreases pore sizes which again makes necessary wider channels [48, 49]. 
In the present study, we extend the use of the swelling agent 1,3,5-triisopropylbenzene (TIPB) to synthesize large pore ordered materials bearing amine groups. We use the principle of large pore sizes in combination with surface functionalization of mesoporous silicas with amino groups for improving the non-covalent immobilization of laccase.

\section{EXPERIMENTAL SECTION}

\subsection{Materials and Reagents}

Chemicals. Triblock co-polymer poly(ethylene oxide)-poly(propylene oxide)poly(ethylene oxide) Pluronic P123 $\left(\mathrm{PEO}_{20} \mathrm{PPO}_{70} \mathrm{PEO}_{20}\right)$, from Aldrich (USA), was used as structure directing agent. Tetraethoxysilane (TEOS) (Merck, Germany) and 3aminopropyltriethoxysilane (APTS) were provided by TCI (Belgium). Ammonium fluoride $\left(\mathrm{NH}_{4} \mathrm{~F}\right)$ and 1,3,5-triisopropylbenzene (TIPB) were from Alfa Aesar (Germany). 2'-azino-bis-(3-ethylbenzothiazoline-6-sulfonic acid) diammonium salt (ABTS) was from Sigma (USA). Amorphous silica MS-3030 was kindly donated by Silica PQ Corporation (USA).

The extract of soluble laccase (Suberase) from Myceliophthora thermophila expressed in Aspergillus oryzae was kindly donated by Novozymes (Denmark). Bovine serum albumin (BSA, Sigma-Aldrich, USA) was used as protein standard for protein content determination by the Bradford method [50]. The reagents for electrophoresis (SDSPAGE) and broad molecular weight standards were from Bio-Rad (USA).

Potassium chloride, phosphoric acid, citric acid and toluene were purchased from Sigma-Aldrich (USA). Sodium acetate was purchased from Scharlau (Spain). Sodium di-hydrogen phosphate 1-hydrate, hydrochloric acid, ethanol, acetic acid and acetone 
were purchased from Panreac (Spain). Tri-sodium citrate dehydrate was from Analyticals Carlo Erba (Italy). Solvents were all analytical or HPLC grade and salts were of high purity. All materials were used as obtained without further purification. Water was grade Milli-Q.

\subsection{Synthesis of supports}

\subsubsection{Synthesis of large-pore SBA-15 silica}

The synthesis of ordered mesoporous silica with two-dimensional hexagonal arrangement of pore channels (SBA-15) was carried out using 1,3,5-triisopropylbenzene as micelle expander to obtain a large-pore material. The procedure was based on a previously reported method $[8,18]$, which was slightly modified. $\mathrm{NH}_{4} \mathrm{~F}$ was used to facilitate hydrolysis and condensation of the silica source [51]. Typically, $2.4 \mathrm{~g}$ of triblock co-polymer Pluronic P123 and $0.027 \mathrm{~g}$ of $\mathrm{NH}_{4} \mathrm{~F}$ were dissolved at room temperature in $84.0 \mathrm{~mL}$ of $1.30 \mathrm{M}$ aqueous $\mathrm{HCl}$ solution, in a closed container made of Teflon, using a magnetic stirrer. The container was then transferred to a water bath kept at a temperature of $20{ }^{\circ} \mathrm{C}$ and the solution gently stirred for 1 hour to allow for temperature equilibration. Then, a mixture of $5.5 \mathrm{~mL}$ of TEOS and $1.2 \mathrm{~mL}$ of micelle expander TIPB was added. The white gel obtained was vigorously stirred for $24 \mathrm{~h}$ at 20 ${ }^{\circ} \mathrm{C}$ and subsequently heated at $100{ }^{\circ} \mathrm{C}$ in the closed container under static conditions for 2 days. The mixture was then filtered and the solid product was washed with water and dried at room temperature. Finally, the sample was calcined in a furnace for $5 \mathrm{~h}$ at 550 ${ }^{\circ} \mathrm{C}$ (heating ramp: $2{ }^{\circ} \mathrm{C} / \mathrm{min}$ ). Complete surfactant removal was verified by thermogravimetric analysis (TGA). This material was labelled as OES (Ordered Expanded Silica). 


\subsubsection{Synthesis of aminopropyl-functionalized supports by grafting}

Large-pore silica (OES) and commercial mesoporous amorphous silica MS-3030 (AS) were functionalized with aminopropyl groups by reaction of surface hydroxyls with APTS. The silica powder (1.1 g) was introduced in a round bottom flask and degassed at $80{ }^{\circ} \mathrm{C}$ under vacuum for $18 \mathrm{~h}$ to remove adsorbed water. The dried material was dispersed in $100 \mathrm{~mL}$ of dry toluene, then $0.96 \mathrm{~mL}$ of 3-aminopropyltriethoxysilane were added and the mixture was refluxed at atmospheric pressure under $\mathrm{N}_{2}$ for $24 \mathrm{~h}$. The suspension was then filtered, washed twice with dry toluene and three times with acetone and finally dried at room temperature for $24 \mathrm{~h}$. The functionalized nitrogenbearing supports obtained were designated NGOES (N Grafted Ordered Expanded Silica) and NAS (N Amorphous Silica).

\subsubsection{Synthesis of aminopropyl-functionalized silica SBA-15 by co-condensation}

Amine-functionalized mesoporous SBA-15 silica obtained by a one-pot synthesis method (co-condensation) was synthesized following the procedure previously reported to incorporate other functional groups into mesostructured silica [23, 46, 52]. The synthesis was performed with the addition of the micelle expander TIPB.

Pluronic P123 (4 g) was dissolved at room temperature in $125 \mathrm{~mL}$ of $1.9 \mathrm{M} \mathrm{HCl}$ aqueous solution. After cooling to $18^{\circ} \mathrm{C}, 8.21 \mathrm{~mL}$ of TEOS and $2 \mathrm{~mL}$ of TIPB were added to the solution, and the mixture kept under stirring for $45 \mathrm{~min}$. Then, $0.96 \mathrm{~mL}$ of APTS were slowly added. The resulting mixture was stirred at $18^{\circ} \mathrm{C}$ for $20 \mathrm{~h}$ and then aged at $100{ }^{\circ} \mathrm{C}$ under static conditions for $24 \mathrm{~h}$. The solid product was recovered by filtration and dried at room temperature for $24 \mathrm{~h}$. The surfactant and TIPB were removed from the material by solvent extraction: $1 \mathrm{~g}$ of solid was added to $140 \mathrm{~mL}$ of ethanol and refluxed for $24 \mathrm{~h}$, followed by filtration, washing several times with ethanol 
and drying at room temperature for $24 \mathrm{~h}$. The resultant sample is denoted as NCOES (Nitrogen-bearing Co-condensed Ordered Expanded Silica).

\subsection{Characterization}

Mesoscopic order was investigated by Low-angle X-Ray Diffraction (XRD). Patterns of the samples were obtained with a Philips X’PERT diffractometer using $\mathrm{Cu} \mathrm{K}_{\alpha}$ radiation. Nitrogen adsorption-desorption isotherms were measured at $-196{ }^{\circ} \mathrm{C}$ using the Micromeritics ASAP 2020 and ASAP 2420 sorptometers to determine textural properties. Pure silicas were pretreated at $350{ }^{\circ} \mathrm{C}$ for $16 \mathrm{~h}$ and the functionalized supports, at $120{ }^{\circ} \mathrm{C}$ for $16 \mathrm{~h}$. The total pore volume, $V_{p}$, was determined from the amount of nitrogen adsorbed at a relative pressure of 0.97 . Pore size distributions were determined from the adsorption branches of isotherms using the Barrett-Joyner-Halenda $(\mathrm{BJH})$ model with cylindrical geometry of the pores [53]. The $\mathrm{BJH}$ pore diameter, $D_{p}$ ${ }_{B J H}$, is defined as the position of the maximum of the pore size distribution.

Quantitative determination of the nitrogen content of organo-functionalized supports was performed using a LECO CHNS-932 Elemental Analyser with a Perkin Elmer AD4 autobalance.

Thermogravimetric analyses were carried out using a Perkin Elmer TGA 7 instrument Samples were heated in air atmosphere from 25 to $900{ }^{\circ} \mathrm{C}$ at a rate of $20^{\circ} \mathrm{C} / \mathrm{min}$.

Transmission electron micrographs (TEM) were taken using a JEOL 2100 electron microscope operating at $200 \mathrm{kV}$. The samples for TEM analysis were prepared by suspending a small amount of solid in acetone using sonication in an ultrasonication water bath for 5 min. A drop of this suspension was then dispersed onto a holey carbon film on a copper grid, followed by drying at room temperature. 
Scanning electron microscopy (SEM) micrographs were collected with a FE-SEM FEI Nova Nanosem 230 microscope with vCD detector. The samples were prepared by placing material powder on double-sided graphite adhesive tape mounted on the sample holder.

\subsection{Laccase activity assay}

Laccase activity was determined spectrophotometrically by measuring the increase in absorbance at $405 \mathrm{~nm}$ caused by the oxidation of ABTS $[36,54,55]$ at $25^{\circ} \mathrm{C}$, using an Agilent 8453 UV-Vis spectrophotometer equipped with a stirring device and temperature control. The reaction mixture consisted of a $1.6 \mathrm{mM}$ ABTS solution in 100 $\mathrm{mM}$ acetic acid/sodium acetate buffer at $\mathrm{pH} 4.5$. To $1.9 \mathrm{~mL}$ of this solution in the cuvette, $50 \mu \mathrm{L}$ of enzyme solution or suspension were added under stirring and the reaction was monitored continuously for 30 min by measuring the absorption at $405 \mathrm{~nm}$. One unit of Laccase $(U)$ was defined as the amount of enzyme required to oxidize 1 $\mu$ mol of ABTS per minute at $25^{\circ} \mathrm{C}\left(\varepsilon_{405 \mathrm{~nm}}=35,000 \mathrm{M}^{-1} \cdot \mathrm{cm}^{-1}\right)$.

\subsection{Protein determination}

Protein content of solutions was determined with the Bio-Rad Protein Assay (Bio-Rad, USA), based on the Bradford assay [50], using bovine serum albumin (BSA) as protein standard. The Suberase commercial extract was found to contain a protein concentration of $3.283 \mathrm{mg} / \mathrm{mL}$.

SDS-polyacrylamide gel electrophoresis (SDS-PAGE) was performed for identification of the enzyme and the purity of the commercial extract [56].

Bioinformatics analysis was used to determine the aminoacid sequence and 3D structure of Myceliophthora thermophila laccase $(M t \mathrm{~L})$ because the crystal structure is not resolved yet and its dimensions have not been reported. An existing aminoacid sequence 
from $M t \mathrm{~L}$ in the NCBI Protein Database [57] (accession number AEO 58496.1) was used as a template to identify homologous sequences of the laccase in BLASTP algorithm [58]. The protein BLAST analysis for $M t \mathrm{~L}$ showed that it shares high identity (73\%) and high query coverage (99\%) with Melanocarpus albomyces laccase (PDB: 1GWO-A) [59, 60].

The 3D structure of $M t \mathrm{~L}$ was modeled applying the alignment mode on the Swiss model server [58, 61-64] using the three-dimensional structure of the Melanocarpus albomyces laccase. The modeled $M t \mathrm{~L}$ structure has been visualized using Pymol software [65].

The molecular analysis of the whole protein using the tools ProtParam [66], UniProt KB (G2QFD0 and G2Q560) [67, 68] and Brenda [69] showed that it has a molecular weight between 63 and $85 \mathrm{kDa}$. The predicted isoelectric point (pI) was found to be 4.2. These data do not differ significantly from other authors [70], who reported a molecular weight of $80 \mathrm{kDa}$ for the glycosylated protein and $73 \mathrm{kDa}$ upon deglycosilation, and a pI of 4.2.

Laccase from Melanocarpus albomyces (1GWO) has been used to perform an estimation of the molecular dimensions of $M t$ laccase used in this work. These dimensions were calculated from the composition of the peptide chain by simulation using the program PyMOL. From these data, approximate dimensions have been estimated as $6.3 \times 7.2 \times 8.9 \mathrm{~nm}$.

\subsection{Immobilization of laccase on mesoporous silicates}

Immobilization of laccase on purely siliceous supports, namely OES and AS, was performed by suspending the materials in enzyme solutions at $\mathrm{pH} 3.5(50 \mathrm{mM}$ citric acid/trisodium citrate buffer). Hybrid amino-silica materials NAS, NGOES and NCOES 
were suspended in laccase solutions in $50 \mathrm{mM}$ acetic acid/sodium acetate buffer at $\mathrm{pH}$

\section{5 .}

To $10 \mathrm{~mL}$ enzyme solutions, $50 \mathrm{mg}$ of the respective mesoporous material were added and left in suspension under mild stirring at room temperature to permit immobilization to occur by adsorption. Aliquots were withdrawn at given times, and the enzymatic activity of the suspension and supernatant were analyzed by the ABTS oxidation assay. The decrease in activity of the supernatant to a minimum and constant value indicated the end point of the immobilization process. Protein content of the supernatant was measured to calculate the immobilization yield. At this point, the solid was separated by vacuum filtration using a quartz fritted disk and washed with acetate buffer $(50 \mathrm{mM}$, at the same $\mathrm{pH}$ as used for immobilization, 3.5 or 5.5). No protein was detected in these washings. The solid samples were then dried under vacuum and afterwards under dry nitrogen stream, and were stored at $4{ }^{\circ} \mathrm{C}$ for later analysis. For the determination of immobilized enzyme activity, $10 \mathrm{mg}$ of the respective biocatalysts were resuspended in $1 \mathrm{~mL} 50 \mathrm{mM}$ acetate buffer $(\mathrm{pH} 3.5$ for biocatalysts prepared with purely siliceous supports or $\mathrm{pH} 5.5$ for those on amino-silica supports) and analyzed for remaining laccase activity by the ABTS oxidation assay.

In order to determine the maximum enzyme loading attainable for each support, adsorption isotherms were obtained by carrying out the same immobilization procedure described above with various enzyme to support ratios in the range from 25 to 400 $\mathrm{mg} / \mathrm{g}$. Enzyme concentration in the solutions was changed but the final volume was always $10 \mathrm{~mL}$ in order to keep a constant solution to support ratio.

\subsection{Effect of pH on laccase activity}

The activity assays of the free and immobilized laccases were performed as a function of $\mathrm{pH}$ at $25^{\circ} \mathrm{C}$, following the procedure described in section 2.4. ABTS solutions were 
prepared at $\mathrm{pH}$ ranging between 2.5 and 6.0 in $0.05 \mathrm{M}$ phosphoric acid/sodium dihydrogenphosphate $(\mathrm{pH} 2.0)$ and $0.05 \mathrm{M}$ citric acid/trisodium citrate ( $\mathrm{pH} 3.0,3.5,4.0$, $4.5,5.0,6.0)$ at $25^{\circ} \mathrm{C}$ (triplicated). In order to perform enzyme spectrophotometric assays at different $\mathrm{pH}$ values, the isosbestic point of oxidized ABTS (ABTS*) was determined. This value was found to be $430 \mathrm{~nm}$. The molar absorption coefficient of ABTS* measured at these wavelength was $\varepsilon_{430 \mathrm{~nm}}=20,700 \mathrm{M}^{-1} \mathrm{~cm}^{-1}$, independent of the $\mathrm{pH}$.

\subsection{Leaching}

The resistance of the enzyme to leach from the support was studied under conditions that presumably favor the release of the protein, namely high dilution and low ionic strength. The catalysts were incubated in $50 \mathrm{mM}$ acetic acid/sodium acetate buffer at $\mathrm{pH}$ 4.5 and the solid/total volume ratio was $1.25 \mathrm{mg}$ of solid per $\mathrm{mL}$ of buffer. Enzymesupport interactions at this $\mathrm{pH}$ are weak and the effect of support structure on leaching prevention can be observed. Enzyme leaching was calculated by monitoring the appearance of enzyme in the supernatant with the Bradford assay [50].

Enzyme molecules immobilized on the external surface of the particles or in the mouths of the pore channels are released more easily than those supposedly immobilized deep inside the pores. It is interesting to check if most of the enzyme is located inside pore channels. Since solid samples are not suitable for electrophoresis, the enzyme was forced to exit the pores. First, the laccase immobilized on different materials (NGOES and NCOES) was suspended in buffered solutions as described above to desorb as much enzyme as possible, especially to eliminate all protein molecules adsorbed on the external surface of support particles. The supernatants containing the released protein were separated, and the filtered solids were suspended in electrophoresis sample buffer 
(containing Sodium Dodecyl Sulfate, mercaptoethanol, bromophenol blue, Tris buffer pH 6.8 and glycerol) in the same amounts as in electrophoresis samples, and boiled for 5 min. In such denaturing conditions including the split of disulfide bonds favored by the presence of mercaptoethanol, the tertiary structure of the protein should be lost and the random coil chain should then be easily released from the pores. The supernatants of these suspensions were withdrawn and analyzed by SDS-PAGE electrophoresis. The solids corresponding to samples that did not show bands were again boiled in electrophoresis buffer and filtrated and then additionally suspended for one to two hours in a $\mathrm{NaOH}$ solution at $\mathrm{pH}$ 11.0. All amino groups from support and enzyme should be deprotonated in these alkaline solution and repulsive forces should be driving the release of protein from pore channels. These new supernatants were also analyzed by SDS-PAGE electrophoresis.

\subsection{Thermal stability test}

Thermal stability was determined by incubating free or immobilized laccases in $50 \mathrm{mM}$ acetic acid/sodium acetate buffer at $\mathrm{pH} 3.5$ (for biocatalysts supported on purely siliceous materials) or $\mathrm{pH} 5.5$ (for amino-silica supported biocatalysts and free laccase) at $50{ }^{\circ} \mathrm{C}$ for different time periods. Incubations were performed in individual vials for each aliquot to prevent evaporation. The $\mathrm{pH}$ values were selected to avoid or minimize enzyme leaching and ensure that the measured activity corresponded only to the immobilized enzyme. Aliquots of the suspensions of the catalysts were withdrawn, cooled and immediately assayed spectrophotometrically in the oxidation of ABTS $(\lambda=$ $405 \mathrm{~nm})$.

\subsection{Evaluation of enzyme stability in the presence of ethanol}

The organic medium was selected on the basis of a possible application of the laccase biocatalysts in controlled oxidation of wine polyphenols. Therefore the stability of the 
enzyme was studied by incubating free and immobilized enzyme at $25^{\circ} \mathrm{C}$ for variable time periods in conditions similar to those of wine, i.e., $10 \% \mathrm{v} / \mathrm{v}$ ethanol/water solution at $\mathrm{pH} 3.5(50 \mathrm{mM}$ citric acid/trisodium citrate). Incubations were performed in individual vials for each aliquot, thereby preventing evaporation. Then the remaining laccase activity of the suspensions was assayed at $25^{\circ} \mathrm{C}$ in standard conditions with $\operatorname{ABTS}(\lambda=405 \mathrm{~nm})$.

\section{RESULTS AND DISCUSSION}

Various mesoporous silica and amino-functionalized silica materials with pore diameter larger than $10 \mathrm{~nm}$ were synthesized to host the laccase. The pore size of these mesoporous materials was tailored by the addition of a swelling agent (1,3,5triisopropylbenzene) to expand the Pluronic P123 micelles as described in the experimental section $[9,20,71,72]$. Commercial amorphous silica (AS) was also used as support for comparison purposes.

\subsection{Characterization of the supports}

Figure 1 shows the XRD patterns of samples OES, NCOES and NGOES. The diffractogram of sample OES shows three well-resolved peaks corresponding to the 100,110 and 200 reflections characteristic of the $p 6 \mathrm{~mm}$ hexagonal symmetry, which confirms that this silica sample possesses a highly ordered SBA-15 type of structure $[10,17]$. The diffractogram of sample NGOES indicates that it also possesses a highly ordered 2D hexagonal structure, indicating that grafting of aminopropyl groups on sample OES do not affect the pore ordering. This is also supported by TEM images of sample NGOES that evidence the well-ordered hexagonal arrangement of mesopore channels (Figure $2 a, b$ ). In the case of the amino-functionalized silica obtained by co- 
condensation (sample NCOES), the diffractogram (Figure 1) shows an intense peak at low angle that indicates that this sample is mesostructured. Weak shoulders can also be observed at $2 \theta$ angles around $1.5^{\circ}$, which might be assigned to the 110 and 200 reflections of the $p 6 \mathrm{~mm}$ space group, although the fact that these reflections are not well resolved suggests that pore ordering in sample NCOES might be restricted to smaller domains compared to samples OES and NGOES. Nevertheless, TEM images (Figure 2 $c, d$ ) show that sample NCOES possesses an ordered arrangement of uniform pore channels corresponding to the SBA-15 structure. In contrast to the former samples, the diffractogram of the commercial amorphous silica sample (AS) (not shown) does not exhibit any diffraction peak at low angle, due the lack of pore ordering in this sample [73].

Nitrogen adsorption-desorption isotherms at $-196{ }^{\circ} \mathrm{C}$ of the supports are plotted in Figure 3, and their corresponding pore size distributions calculated by the BarrettJoyner-Halenda $(\mathrm{BJH})$ method are shown in the inset. The isotherms of samples OES, NGOES and NCOES (Fig. $3 A$ ) show a steep adsorption step at high relative pressure values and a hysteresis loop corresponding to the capillary condensation in large mesopores [53]. The corresponding BJH plots show narrow pore size distributions as expected for samples having uniform pore size. On the other hand, the isotherms of sample AS and its amino-grafted counterpart (Fig. 3 B) show that adsorption in mesopores takes place at higher relative pressure, indicating that these samples contain larger mesopores. Furthermore, their BJH pore size distributions are also much broader than those of the ordered mesoporous supports. Textural properties obtained from the experimental isotherms are collected in Table 1. Nitrogen content of aminofunctionalized samples determined by elemental analysis is also reported in Table 1. These values are given as mmol of nitrogen per gram of silicon dioxide, which 
corresponds to the residual weight determined from the thermogravimetric analyses. The pore diameter determined for sample OES was $15.0 \mathrm{~nm}$, which represents a significant increase respect to the size obtained under similar conditions in the absence of the swelling agent (7.8 $\mathrm{nm}$ [74]). Taking into account the estimated dimensions of the enzyme, it is clear that only expanded materials could be used to ensure efficient laccase diffusion inside the pore channels. This is especially the case if pore surfaces of the support have to be functionalized to improve enzyme immobilization, as grafting of the alkoxysilane precursor would additionally decrease the pore opening. Indeed, the textural data of sample NGOES (Table 1) show that grafting of the OES material with aminopropyl groups led to a decrease of pore size close to $4 \mathrm{~nm}$, along with a small decrease in total pore volume. The decrease of both pore size and total pore volume are consistent with the relatively high loading of aminopropyl moieties obtained, calculated in $1.2 \mathrm{mmol}$ of amine groups per gram of silica, according to the nitrogen content determined by chemical analysis (Table 1).

Compared to the two-steps grafting method, the synthesis of the amino-functionalized silica sample by co-condensation allowed to obtain a support with larger pore size and higher pore volume, and with a higher loading of amine groups (Table 1). However, this material exhibits a broader pore size distribution (Figure $3 \mathrm{~A}$ ), which is in agreement with its poorer pore ordering. The amorphous silica sample (AS) exhibits textural properties notably different from those of the ordered mesoporous supports. The BJH pore size distribution (Figure $3 B$ ) shows that the former sample possesses pores in the range of 10-60 $\mathrm{nm}$, with the maximum of the distribution around $30 \mathrm{~nm}$. Therefore, it contains larger and less uniform pores. The pore volume of sample AS is also much higher, reaching $2.5 \mathrm{~cm}^{3} / \mathrm{g}$. This sample allows for a large amount of aminopropyl species to be anchored on its surface by grafting, as indicated by the nitrogen content 
determined for sample NAS (Table 1), equivalent to 1.8 amine groups per gram of silica. As expected, this high level of surface modification produces a substantial decrease of pore volume, which nevertheless remains close to twice the pore volume of the amino-functionalized ordered silica supports. However, the effect on pore size is negligible due to the large pore dimensions.

SEM images of samples OES (Fig. S1 $a$ ) and NGOES (Fig. S1 $b$ ) show particles with a fiberlike morphology, which consist of small agglomerated rod shaped primary particles of several tens of microns in length and a thickness of about $1 \mu \mathrm{m}$. This morphology is characteristic of the material SBA-15 [17]. In contrast, the SEM image of NCOES (Fig. S1 c) displays predominantly agglomerated fibrous particles and that of NAS (Fig. S1 d) shows fragmented spherical particles several tens of microns in size.

\subsection{Laccase immobilization}

To carry out the immobilization of the enzyme on the supports by electrostatic interactions, the solids should be suspended in an enzyme solution at a $\mathrm{pH}$ intermediate between the isoelectric point of the support and that of the laccase. The pI of purely siliceous supports is 2.0 , while that of laccase is 4.2 , therefore, the selection of $\mathrm{pH} 3.5$ may allow to establish electrostatic interaction between the positevely charged enzyme and the negatively charged support (Figure $4 A$ ). However, this $\mathrm{pH}$ is very close to $\mathrm{pI}$ of both the support and the enzyme, leading to a weak driving force for adsorption, which in turn produces low enzyme loadings, around 14-16 mg per gram of support for samples OES and AS (Table 1).

By introduction of primary amine groups (with $\mathrm{pK}_{a}$ around 10) on the surface of the support, the balance of charges can be reversed and immobilization may be driven in a wider $\mathrm{pH}$ range, between 4 and 10, which allows to work at $\mathrm{pH}$ values far from the $\mathrm{pI}$ of 
both the support and the enzyme, and thus higher charge density on both species can be established and drive a stronger interaction (Figure $4 \mathrm{~B}$ ).

Immobilization on amino-modified supports was therefore performed at $\mathrm{pH} 5.5$, at which the amino groups of the support are positively charged and the net charge of the enzyme is negative as seen in Figure $4 \mathrm{~B}$. The different supports were suspended in solutions with increasing enzyme concentrations for immobilization. Figure 5shows the relationship between the initial amount of enzyme in solution per gram of support in suspension and the actual enzyme loading achieved at adsorption equilibrium. For all the supports, the enzyme loading showed a continuous increase with the total enzyme to support mass ratio until a plateau is reached, which means that the maximum capacity of the support has been reached. The maximum adsorption amounts determined were $187 \mathrm{mg} / \mathrm{g}$ for NAS and around $170 \mathrm{mg} / \mathrm{g}$ for NGOES and NCOES (Table 1). These adsorption curves follow a Langmuir model, that is, their shape indicates that immobilization takes place forming an enzyme monolayer. This behavior is expected for the confinement of enzyme in the narrow pores of the two ordered mesoporous supports, which does not permit the formation of a multilayer. However, multilayer adsorption would be possible on the external surface of the particles or within the large pores of the NAS support. The lack of multilayer adsorption also in these cases can be attributed to electrostatic repulsion among enzyme molecules, as the enzyme surface should possess a significant net negative charge at the $\mathrm{pH}$ used for immobilization, well above the isoelectric point of the enzyme.

The adsorption isotherm obtained for sample NAS shows a constant slope in the low enzyme concentration region and an abrupt change of slope at the enzyme concentration at which the plateau is reached. On the contrary, the isotherms of the two OMM supports show a progressive decrease of slope with the increase of enzyme 
concentration until the plateau is reached. This different behavior suggests that diffusion of enzyme inside the narrow pore channels of the OMM supports is progressively more restricted as the loading of enzyme increases, while the large pores of the NAS support would allow enzyme diffusion to be independent of surface coverage. Taking into account these considerations, it is worth determining whether the maximum loading of enzyme obtained for the OMM supports corresponds to a complete filling of pores by enzyme molecules. The estimated dimensions of the enzyme are $6.3 \times 7.2 \times 8.9 \mathrm{~nm}$, and its approximate volume is $402 \mathrm{~nm}^{3}$. Hence, the maximum enzyme loading can be estimated in $2.5 \cdot 10^{18}$ molecules per $\mathrm{cm}^{3}$ of pore volume. According to its amino acid sequence, the molecular weight of the enzyme would be around $73 \mathrm{kDa}$. Thus, the maximum loading achieved for the OMM supports (around $170 \mathrm{mg}$ of enzyme per $\mathrm{cm}^{3}$ of pore volume) would be equivalent to $60 \%$ of the theoretical maximum laccase loading. Indeed, the actual filling of pore volume must be higher than $60 \%$, as this calculation does not consider the glycosylation of the protein [70]. Glycosylation explains that the band determined by electrophoresis of the Suberase extract shows a molecular weight higher than $73 \mathrm{kDa}$, since the presence of covalently attached carbohydrates often results in incorrect molecular weight values using the SDS-PAGE technique $[55,70,75,76]$.

The purely siliceous materials AS and OES yielded similar low enzyme loading and catalytic efficiency values (Table 1), despite their large differences in pore sizes and structures. The incorporation of amino groups on the surface of these materials leads to a tenfold increase in enzyme loading on both, amorphous and ordered materials. This indicates that the chemical affinity of the enzyme for the surface of the materials is crucial for success in the immobilization of enzymes. Catalytic efficiencies of biocatalysts based on purely siliceous materials OES and AS are some 10 times lower 
than their respective amine-functionalized analogues. In the case of amorphous materials the difference is even more marked, maybe suggesting a better substrate diffusion in this wider pore network.

The pores of the OES support are wide enough to accommodate the laccase molecules even after anchoring propylamine groups on the silica surface as confirmed by the high enzyme loading achieved on the NGOES support, very close to that obtained with the NAS support, which possesses wider pores. Similar loading capacity has been obtained with the amino-functionalized ordered mesoporous silica obtained by co-condensation (NCOES). These results confirm that the tailored pore dimension of the large-pore OMM materials (OES, NGOES and NCOES) allows for diffusion of enzyme through the pore channels.

These results are especially encouraging considering that the Myceliophthora thermophila laccase expressed in Aspergillus oryzae is hyper-glycosylated by eukaryotic host so steric hindrances might prevent interactions between the surface of the enzyme and the functionalized materials [77].

Immobilization of laccase on amine-containing supports is also faster than in purely siliceous materials, as seen by the contact time required to reach the respective maximum loadings (see Table 1). So, by controlling the affinity between enzyme and ordered mesoporous silica, the uptake rate and the maximum loading achieved can be drastically improved.

The orientation of the enzyme with regard to support surface is not an issue with these materials, since confinement of the enzyme in the sufficiently narrow pore channels ensures the same surrounding environment to all enzyme molecules. 


\subsection{Effect of pH on the activity of laccase}

Figure 6 shows relative activity of the laccase at different $\mathrm{pH}$ values in the range 2.5-6.0 determined for the enzyme in solution and immobilized in the different supports.

The activity of laccase shows very similar trend with $\mathrm{pH}$ for the enzyme in solution and immobilized on amorphous silica (AS). In both cases, the maximum activity is obtained at $\mathrm{pH} 3.0$ and there is a strong decrease of activity at both higher and lower $\mathrm{pH}$ values. On the other hand, for the enzyme immobilized on amino-functionalized supports, the maximum activity is obtained at a higher $\mathrm{pH}$ (3.5). This shift of the optimum $\mathrm{pH}$ might be attributed to the existence of a $\mathrm{pH}$ gradient between the solution and the pores of the support due to the presence of anchored amino groups. It can be also observed that, at higher $\mathrm{pH}$, there is a strong decrease of activity for the enzyme supported on the aminofunctionalized amorphous silica (NAS), in a similar way as it occurs for the enzyme supported on the unmodified silica (AS). However, the $\mathrm{pH}$ increase has lower effect on activity for the enzyme supported on NCOES and especially on NGOES, where the activity remains constant. Pore size of NGOES is smaller than NCOES and much smaller than NAS. This suggests that the microenvironment generated by amine groups in the enzyme vicinity is more efficient as these groups are closer to the laccase. In the extreme situations, the wide pore of NAS is not sufficient to maintain the effect over $\mathrm{pH}$ 3.5 whereas the effect of the presence of positive charges close to the enzyme in NGOES remains even at $\mathrm{pH}$ 6.0. These results show that confinement in narrow pore sizes permits to take advantage of the properties of the support.

\subsection{Enzyme leaching}

The non-covalent nature of the enzyme bonding to support makes necessary an evaluation of the potential enzyme leaching. Therefore, all the biocatalysts were 
subjected to leaching experiments, in order to determine whether the confinement in the pores and the enzyme-support electrostatic interaction allow to efficiently and irreversibly entrap the laccase.

Figure 7 shows the relative amount of enzyme that was removed from the different supports along the leaching experiment. Amorphous silica AS and its corresponding amine functionalized form NAS showed a continuous release of enzyme at a nearly constant rate during the whole leaching treatment $(48 \mathrm{~h})$. It can be concluded that the wide pore size of these materials does not offer any restriction for enzyme diffusion and, therefore, leaching can not be prevented under the conditions used (high dilution and low ionic strength).

In contrast the leaching profiles of OMM-supported samples, both purely siliceous and amino-functionalized materials, show an initial desorption during the first two hours of treatment, after which the profiles reach a plateau. Longer incubation times showed no further increase of protein content in the supernatants indicating that no more leaching occurred. These results suggest that confinement of enzyme in narrow pores contributes to prevent leaching of the enzyme, even from the support that was not modified with amino groups to increase its affinity with the enzyme. The initial desorption observed is probably due mainly to removal of enzyme molecules immobilized on the external surface of the OMM particles, which is consistent with the maximum leaching level observed of only $4 \%$ of the enzyme loading or lower. The density of amino groups seems to be less relevant than pore size to determine resistance to leaching, although a lower enzyme leaching was detected with NCOES, the material having the highest amine content $(1.5 \mathrm{mmol} / \mathrm{g})$ among the OMM. Laccase was hardly desorbed (only $2 \%$ ) from this material with pore size slightly larger than enzyme dimensions, and a high density of amine groups that should promote a strong interaction with laccase. It is 
worth emphasizing that this strong retention of the enzyme inside the channels of OMM supports is comparable to a situation of covalently bound enzymes, despite the nature of the linkage is non-covalent.

In order to check the presence of enzyme inside particles, the catalysts previously incubated under the conditions of leaching described above, were treated for SDSPAGE (polyacrylamide gel electrophoresis with sodium dodecyl sulfate) in standard conditions and their supernatants were assayed for electrophoresis (EF). The incubation in 2-mercaptoethanol and SDS at $100{ }^{\circ} \mathrm{C}$ should be severe enough to fully denature the protein and thus enable its release from inner surfaces as a random coil. Thus, a protein band was expected in the corresponding electrophoresis gels. However, these bands were observed (Figure S2) only for the samples corresponding to purely siliceous supports (OES and AS) and the amino-functionalized amorphous silica (NAS). The lack of band in the lanes corresponding to the amine-containing OMM supports (NGOES and NCOES) seems to suggest that laccase was fully retained inside these supports, even as a linear aminoacid chain. The high density of protonated amine groups seems to exert a strong electrostatic interaction also on the denatured protein. In order to confirm the presence of the enzyme inside these materials, the biocatalysts submitted to the leaching treatment followed by the SDS-PAGE denaturing conditions were centrifuged and the supernatant was replaced by the same volume of a $\mathrm{NaOH}$ solution at $\mathrm{pH} 11.0$ to ensure deprotonation of amine groups and, therefore, remove electrostatic interaction between enzyme and support. The samples were incubated for 1-2 hours and then the corresponding supernatants were assayed in EF. As seen in Figure S3 a band corresponding to the same MW as laccase appeared in the electrophoresis gel in the lanes corresponding to NCOES (lane 2) and NGOES (lane 3) supports. 
These results confirm the immobilization of the enzyme inside pores and also explain the absence of leaching of the enzyme. The adsorption process of the laccase indicates a very strong interaction between the functionalized surface and the enzyme, which remains when the protein is in the random coil conformation thus preventing also the desorption of the denatured protein. Only when these interactions disappear at high $\mathrm{pH}$ the leaching occurs.

The total absence of enzyme leaching from a non-covalent immobilization is a promising result since advantages from both kind of bonding can be found in these catalysts, and very interestingly, it permits support reutilization after enzyme inactivation.

\subsection{Thermal stability}

Despite the strong interaction with the support, thermostability was not significantly increased by immobilization. Suspension of the catalysts in aqueous solutions at high temperature $\left(50^{\circ} \mathrm{C}\right)$ did not show significant effects regarding stability. All samples showed similar activity decay with time, comparable to that of the enzyme in solution (Figure 8). Maybe the explanation is related to the fact that laccase from Myceliophthora thermophila is thermoresistant in native state $[68,70]$. Nonetheless it is also likely that partially unfolded and inactive conformation may be stabilized by the proximity of the amino groups of the support.

\subsection{Stability in ethanol-containing solution}

Stability in organic solvent was also tested. Organic cosolvents are known to interfere the hydrogen bonds and thus promote protein unfolding [78]. The solvent of choice was ethanol because one of the possible applications of this enzyme is the partial oxidation 
of wine polyphenols. Catalysts were incubated in a medium similar to wine: $10 \%$ ethanol and acidic $\mathrm{pH}$. Catalytic activity was assayed in ABTS oxidation.

In all cases the immobilization protects from inactivation due to the distortion of the protein structure driven by the organic medium (Figure 9). Confinement of the enzyme within narrow pores and strong interaction with the surface contribute to prevent enzyme unfolding and thus activity can be preserved for longer periods. In all cases, immobilized enzyme showed higher stability than native one. The amorphous and wide pore NAS showed the highest stability the catalysts. NGOES and NCOES showed the same deactivation rate, with half-lives around double than free laccase. [1]. 


\section{CONCLUSION}

Laccase from Myceliophthora thermophile $(M t \mathrm{~L})$ was readily and efficiently immobilized in expanded-pore mesoporous silica supports functionalized with amino groups by means of electrostatic interaction.

Enzymes with large molecular dimensions are difficult to immobilize inside pores of ordered mesoporous materials. The use of micelle expanders like TIPB has been applied to overcome this handicap. Based on this methodology, a strategy of synthesis of expanded pore ordered mesoporous materials (OMM) at low temperature and surface functionalization with amine groups was successfully developed. Laccase was transported through the channels and was effectively immobilized on the inner surfaces with hardly any diffusional restriction. The relatively large diameter of the pores also enabled to anchor functional groups to increase the affinity between the silica support and the enzyme without compromising the diffusion of the enzyme. The good pore connectivity common to OMM facilitates diffusion of substrates and products throughout the porous network. These features of the support materials enabled to obtain nanostructured biocatalysts having high enzyme loading and high catalytic activity in terms of catalytic efficiency, that is, minor loses of activity upon immobilization.

Confinement of enzyme molecules within pores having only slightly larger diameter than enzyme dimension prevents unfolding of protein structure which increases the stability of the biocatalyst in organic medium. The strong interaction with the functional groups of the support contributes to additionally increase enzyme stabilization.

As a result of the tuned pore size and high affinity provided by these materials, the leaching of non-covalently anchored enzyme can be fully prevented. 
Laccase immobilized on NGOES and NCOES displayed high enzyme loading, good activity, good stability and no leaching which are promising properties for industrial application in subsequent reaction cycles. Even after enzyme inactivation, the noncovalent nature of the link may also permit to recover and reutilization of supports, so their advantages can be further exploited with no additional cost.

\section{ACKNOWLEDGMENTS}

The authors thank the Spanish Government for financial support through the project MAT 2012-31127, and Mr. Ramiro Martinez (Novozymes, Spain) for his kind help with the supply of Suberase. V. G. acknowledges Ministerio de Educación, Cultura y Deporte for a FPU PhD fellowship (AP2010-2145). 


\section{REFERENCES}

[1] Y. Han, D. Zhang, Curr. Opin. Chem. Eng., 1 (2012) 129-137.

[2] A. Stein, B.J. Melde, R.C. Schroden, Adv. Mater., 12 (2000) 1403-1419.

[3] M. Hartmann, Chem. Mater., 17 (2005) 4577-4593.

[4] H.H.P. Yiu, P.A. Wright, J. Mater. Chem., 15 (2005) 3690-3700.

[5] X.S. Zhao, X.Y. Bao, W. Guo, F.Y. Lee, MATER TODAY, 9 (2006) 32-39.

[6] J.S. Beck, J.C. Vartuli, W.J. Roth, M.E. Leonowicz, C.T. Kresge, K.D. Schmitt, C.T.W. Chu, D.H. Olson, E.W. Sheppard, J. Am. Chem. Soc., 114 (1992) 10834-10843.

[7] C.T. Kresge, M.E. Leonowicz, W.J. Roth, J.C. Vartuli, J.S. Beck, Nature, 359 (1992) 710-712.

[8] L. Cao, T. Man, M. Kruk, Chem. Mater., 21 (2009) 1144-1153.

[9] Y. Wan, D. Zhao, Chem. Rev., 107 (2007) 2821-2860.

[10] D.Y. Zhao, Q.S. Huo, J.L. Feng, B.F. Chmelka, G.D. Stucky, J. Am. Chem. Soc., 120 (1998) 6024-6036.

[11] M. Kruk, M. Jaroniec, V. Antochshuk, A. Sayari, J. Phys. Chem. B, 106 (2002) 10096-10101.

[12] P.T. Tanev, T.J. Pinnavaia, Science, 267 (1995) 865-867.

[13] J.L. Blin, A. Léonard, B.L. Su, J. Phys. Chem. B, 105 (2001) 6070-6079.

[14] G. Herrier, J.L. Blin, B.L. Su, Langmuir, 17 (2001) 4422-4430. 
[15] K. Cassiers, P. Van der Voort, T. Linssen, E.F. Vansant, O. Lebedev, J. Van Landuyt, J. Phys. Chem. B, 107 (2003) 3690-3696.

[16] J.L. Ruggles, E.P. Gilbert, S.A. Holt, P.A. Reynolds, J.W. White, Langmuir, 19 (2003) 793-800.

[17] D.Y. Zhao, J.L. Feng, Q.S. Huo, N. Melosh, G.H. Fredrickson, B.F. Chmelka, G.D. Stucky, Science, 279 (1998) 548-552.

[18] L. Cao, M. Kruk, Colloids Surf., A, 357 (2010) 91-96.

[19] P. Schmidt-Winkel, W.W. Lukens, D.Y. Zhao, P.D. Yang, B.F. Chmelka, G.D. Stucky, J. Am. Chem. Soc., 121 (1999) 254-255.

[20] J.S. Lettow, Y.J. Han, P. Schmidt-Winkel, P.D. Yang, D.Y. Zhao, G.D. Stucky, J.Y. Ying, Langmuir, 16 (2000) 8291-8295.

[21] E. Serra, V. Alfredsson, R.M. Blanco, I. Diaz, in: A. Gedeon, P. Massiani, F. Babonneau (Eds.) Zeolites and Related Materials: Trends, Targets and Challenges, Proceedings of the 4th International Feza Conference2008, pp. 369-372.

[22] E. Serra, A. Mayoral, Y. Sakamoto, R.M. Blanco, I. Diaz, Microporous Mesoporous Mater., 114 (2008) 201-213.

[23] E. Serra, E. Diez, I. Diaz, R.M. Blanco, Microporous Mesoporous Mater., 132 (2010) 487-493.

[24] A. Leonowicz, N.S. Cho, J. Luterek, A. Wilkolazka, M. Wojtas-Wasilewska, A. Matuszewska, M. Hofrichter, D. Wesenberg, J. Rogalski, J. Basic Microbiol., 41 (2001) 185-227.

[25] A.M. Mayer, R.C. Staples, Phytochem. Rev., 60 (2002) 551-565.

[26] P. Baldrian, FEMS Microbiol. Rev., 30 (2006) 215-242. 
[27] M. Fernandez-Fernandez, M.A. Sanroman, D. Moldes, Biotechnol Adv, 31 (2013) $1808-1825$.

[28] T. Kudanga, G.S. Nyanhongo, G.M. Guebitz, S. Burton, Enzyme Microb. Technol., 48 (2011) 195-208.

[29] M. Pita, C. Gutierrez-Sanchez, D. Olea, M. Velez, C. Garcia-Diego, S. Shleev, V.M. Fernandez, A.L. De Lacey, J. Phys. Chem. C, 115 (2011) 13420-13428.

[30] R.C. Minussi, G.M. Pastore, N. Duran, Trends Food Sci. Tech., 13 (2002) 205-216.

[31] R.C. Minussi, M. Rossi, L. Bologna, L. Cordi, D. Rotilio, G.M. Pastore, N. Duran, Food Chem., 82 (2003) 409-416.

[32] R.C. Minussi, M. Rossi, L. Bologna, D. Rotilio, G.M. Pastore, N. Duran, J. Mol. Catal. B: Enzym., 45 (2007) 102-107.

[33] A. Kunamneni, F.J. Plou, A. Ballesteros, M. Alcalde, Recent patents on biotechnology, 2 (2008) 10-24.

[34] J.F. Osma, J.L. Toca-Herrera, S. Rodriguez-Couto, Enzyme research, 2010 (2010) 918761-918761.

[35] S.R. Couto, J.L.T. Herrera, Bioresour. Technol., 24 (2006) 500-513.

[36] O.V. Morozova, G.P. Shumakovich, S.V. Shleev, Y.I. Yaropolov, Appl. Biochem. Microbiol., 43 (2007) 523-535.

[37] L. Betancor, G.R. Johnson, H.R. Luckarift, Chemcatchem, 5 (2013) 46-60.

[38] K. Brijwani, A. Rigdon, P.V. Vadlani, Enzyme research, 2010 (2010) 149748149748 .

[39] N. Duran, M.A. Rosa, A. D'Annibale, L. Gianfreda, Enzyme Microb. Technol., 31 (2002) 907-931. 
[40] A. Salis, M. Pisano, M. Monduzzi, V. Solinas, E. Sanjust, J. Mol. Catal. B: Enzym., 58 (2009) 175-180.

[41] L. Fernando Bautista, G. Morales, R. Sanz, Bioresour. Technol., 101 (2010) 85418548 .

[42] J. Forde, E. Tully, A. Vakurov, T.D. Gibson, P. Millner, C. O'Fagain, Enzyme Microb. Technol., 46 (2010) 430-437.

[43] D.N. Tran, K.J. Balkus, Jr., ACS Catal, 1 (2011) 956-968.

[44] A. Mayoral, R. Arenal, V. Gascon, C. Marquez-Alvarez, R.M. Blanco, I. Diaz, Chemcatchem, 5 (2013) 903-909.

[45] A.S.M. Chong, X.S. Zhao, J. Phys. Chem. B, 107 (2003) 12650-12657.

[46] X.G. Wang, K.S.K. Lin, J.C.C. Chan, S. Cheng, Chem. Commun., (2004) 27622763.

[47] J. Aguado, J.M. Arsuaga, A. Arencibia, M. Lindo, V. Gascon, J. Hazard. Mater., 163 (2009) 213-221.

[48] Y. Han, S.S. Lee, J.Y. Ying, Chem. Mater., 18 (2006) 643-649.

[49] H.G. Manyar, E. Gianotti, Y. Sakamoto, O. Terasaki, S. Coluccia, S. Tumbiolo, J. Phys. Chem. C, 112 (2008) 18110-18116.

[50] M.M. Bradford, Anal. Biochem., 72 (1976) 248-254.

[51] Z. Jin, X. Wang, X. Cui, J NON-CRYST SOLIDS, 353 (2007) 2507-2514.

[52] D. Margolese, J.A. Melero, S.C. Christiansen, B.F. Chmelka, G.D. Stucky, Chem. Mater., 12 (2000) 2448-2459.

[53] K.S.W. Sing, Pure Appl. Chem., 57 (1985) 603-619. 
[54] A. SanchezAmat, F. Solano, Biochemical and Biophysical Research Communications, 240 (1997) 787-792.

[55] J.I. Lopez-Cruz, G. Viniegra-Gonzalez, A. Hernandez-Arana, Bioconjugate Chem., 17 (2006) 1093-1098.

[56] U.K. Laemmli, Nature, 227 (1970) 680-685.

[57] NCBI Protein Database, http://www.ncbi.nlm.nih.gov/protein, 14/01/14

[58] Standard Protein BLAST, http://swissmodel.expasy.org/?pid=smd05, 14/01/14

[59] RCSB Protein Data Bank, http://www.rcsb.org/pdb/home/home.do, 14/01/14

[60] N. Hakulinen, L.L. Kiiskinen, K. Kruus, M. Saloheimo, A. Koivula, J. Rouvinen, Nat. Struct. Biol., 9 (2002) 601-605.

[61] E. Gasteiger, A. Gattiker, C. Hoogland, I. Ivanyi, R.D. Appel, A. Bairoch, Nucleic Acids Res., 31 (2003) 3784-3788.

[62] K. Arnold, L. Bordoli, J. Kopp, T. Schwede, Bioinformatics, 22 (2006) 195-201.

[63] L. Bordoli, F. Kiefer, K. Arnold, P. Benkert, J. Battey, T. Schwede, Nat. Protoc., 4 (2009) 1-13.

[64] F. Kiefer, K. Arnold, M. Kuenzli, L. Bordoli, T. Schwede, Nucleic Acids Res., 37 (2009) D387-D392.

[65] The PyMOL Molecular Graphics System, http://www.pymol.org/, 14/01/14

[66] ExPASy - ProtParamtool, http://web.expasy.org/protparam/, 14/01/14

[67] UniProt KB, http://www.uniprot.org/uniprot/G2QFD0, 14/01/14 
[68] R.M. Berka, I.V. Grigoriev, R. Otillar, A. Salamov, J. Grimwood, I. Reid, N. Ishmael, T. John, C. Darmond, M.C. Moisan, B. Henrissat, P.M. Coutinho, V. Lombard, D.O. Natvig, E. Lindquist, J. Schmutz, S. Lucas, P. Harris, J. Powlowski, A. Bellemare, D. Taylor, G. Butler, R.P. de Vries, I.E. Allijn, J. van den Brink, S. Ushinsky, R. Storms, A.J. Powell, I.T. Paulsen, L.D. Elbourne, S.E. Baker, J. Magnuson, S. Laboissiere, A.J. Clutterbuck, D. Martinez, M. Wogulis, A.L. de Leon, M.W. Rey, A. Tsang, Nat. Biotechnol., 29 (2011) 922-927.

[69] http://www.brenda-enzymes.org/php/result_flat.php4?ecno=1.10.3.2, 14/01/14

[70] R.M. Berka, P. Schneider, E.J. Golightly, S.H. Brown, M. Madden, K.M. Brown, T. Halkier, K. Mondorf, F. Xu, Appl. Environ. Microbiol., 63 (1997) 3151-3157.

[71] D.Y. Zhao, J.Y. Sun, Q.Z. Li, G.D. Stucky, Chem. Mater., 12 (2000) 275-+.

[72] M. Mandal, M. Kruk, J. Mater. Chem., 20 (2010) 7506-7516.

[73] V. Meynen, P. Cool, E.F. Vansant, Microporous Mesoporous Mater., 125 (2009) 170-223.

[74] V. Gascon, C. Marquez-Alvarez, R.M. Blanco, Molecules, (2014).

[75] C. Hart, B. Schulenberg, T.H. Steinberg, W.Y. Leung, W.F. Patton, Electrophoresis, 24 (2003) 588-598.

[76] J. Wu, N.J. Lenchik, M.J. Pabst, S.S. Solomon, J. Shull, I.C. Gerling, Electrophoresis, 26 (2005) 225-237.

[77] A. Kunamneni, B. Cutino-Avila, D.F. Gil, A. Del Monte, M. Alcalde, A. Ballesteros, F.J. Plou, New Biotechnol., 25 (2009) S135-S135.

[78] V.V. Mozhaev, Y.L. Khmelnitsky, M.V. Sergeeva, A.B. Belova, N.L. Klyachko, A.V. Levashov, K. Martinek, Eur. J. Biochem., 184 (1989) 597-602. 


\section{TABLES}

Table 1. Textural properties and degree of functionalization of the supports, laccase immobilization characteristics and catalytic performance.

\begin{tabular}{|c|c|c|c|c|c|c|c|c|}
\hline Material & $\begin{array}{c}D_{p B J H}{ }^{[a]} \\
\quad(\mathbf{n m})\end{array}$ & $\begin{array}{c}V_{p}^{[b]} \\
\left(\mathrm{cm}^{3} / \mathrm{g}\right)\end{array}$ & $\begin{array}{c}S_{B E T}^{[c]} \\
\left(\mathrm{cm}^{3} / \mathrm{g}\right)\end{array}$ & $\begin{array}{c}\mathbf{m m o l} \\
\mathrm{N} / \mathrm{g}^{[d]} \\
\mathrm{SiO}_{2}^{[d]}\end{array}$ & $\begin{array}{l}t_{c}^{[e]} \\
(\mathbf{h})\end{array}$ & $\begin{array}{c}\text { Max. } \\
\text { loading } \\
(\mathbf{m g} / \mathbf{g})\end{array}$ & $\begin{array}{c}\text { Biocatalyst } \\
\text { activity } \\
\text { (U/g) }\end{array}$ & $\begin{array}{l}\text { Cat. Eff } \\
{ }_{[h]}(\mathbf{U} / \mathbf{m g})\end{array}$ \\
\hline OES & 15.0 & 1.2 & 427 & - & 24 & 14.2 & 0.56 & 0.04 \\
\hline NGOES & 11.2 & 1.0 & 339 & 1.2 & 2.0 & 170.0 & 50.7 & 0.30 \\
\hline NCOES & 17.6 & 1.2 & 385 & 1.5 & 3.5 & 173.8 & 56.0 & 0.32 \\
\hline AS & $\sim 30$ & 2.5 & 296 & - & 24 & 15.8 & 0.52 & 0.03 \\
\hline NAS & $\sim 30$ & 2.1 & 236 & 1.8 & 24 & 187.1 & 169.5 & 0.91 \\
\hline
\end{tabular}

[a] BJH pore diameter $(\mathrm{nm})$ calculated from adsorption branch.

[b] Pore volume $\left(\mathrm{cm}^{3} / \mathrm{g}\right)$ estimated at a relative pressure of 0.97 .

[c] BET surface area $\left(\mathrm{m}^{2} / \mathrm{g}\right)$.

[d] Amine groups incorporated in the silica framework $=\mathrm{mmol} \mathrm{N} / \mathrm{g} \mathrm{SiO}_{2}=(\mathrm{mmol} \mathrm{N} / \mathrm{g}$ material $)$ / \%final weight (TGA)

$[e]$ Time at which the maximum enzyme loading is achieved

[f] Maximum enzyme loading, expressed in milligrams of enzyme per gram of biocatalysts.

$[g]$ Biocatalyst activity (Units/g biocatalysts) in ABTS test.

[h] Catalytic efficiency = Activity versus loading (Units/mg enzyme). The activity of enzyme in solution was $1.25 \mathrm{U} / \mathrm{mg}$. 


\section{FIGURE CAPTIONS}

Figure 1. Low-angle XRD patterns of ordered mesoporous silica and aminofunctionalized silica supports.

Figure 2. TEM micrographs of samples NGOES $(a, b)$ and NCOES $(c, d)$.

Figure 3. Nitrogen adsorption-desorption isotherms and pore size distributions of mesoporous silica and amino-silica supports. The isotherms have been shifted vertically for clarity (A) NCOES +400; OES +200; NGOES +0. B) AS +700).

Figure 4. Laccase immobilization on $(A)$ siliceous materials without amino groups and (B) supports with amino groups.

Figure 5. Equilibrium loading of immobilized enzyme versus initial enzyme content in solution at $\mathrm{pH} 5.5$ for amino-modified supports.

Figure 6 Effect of $\mathrm{pH}$ on the activity of $a$ ) free enzyme (!) and enzyme immobilized on b) AS $(\beta), c)$ NGOES $(), d$,$) NCOES (8), e) NAS (\psi)$. Oxidation of ABTS at $25{ }^{\circ} \mathrm{C}$ in $0.05 \mathrm{M}$ phosphoric acid/sodium dihydrogenphosphate or $0.05 \mathrm{M}$ citric acid/trisodium citrate buffer solutions.

Figure 7. Leaching of enzyme from channel-like materials and amorphous mesoporous silica, expressed as percent of the initial enzyme loading leached as a function of time.

Figure 8. Thermostability profiles of free and immobilized laccase. Oxidation of ABTS at $50{ }^{\circ} \mathrm{C}$ in $50 \mathrm{mM}$ acetic acid/sodium acetate buffer at $\mathrm{pH} 5.5$

Figure 9. Stability tests of free and immobilized laccase in acidic aqueous solution containing ethanol (10 vol\% ethanol in $50 \mathrm{mM}$ citric acid/trisodium citrate buffer at $\mathrm{pH}$ 3.5). Oxidation of ABTS was performed at $25^{\circ} \mathrm{C}$. 
FIGURES

Figure 1.

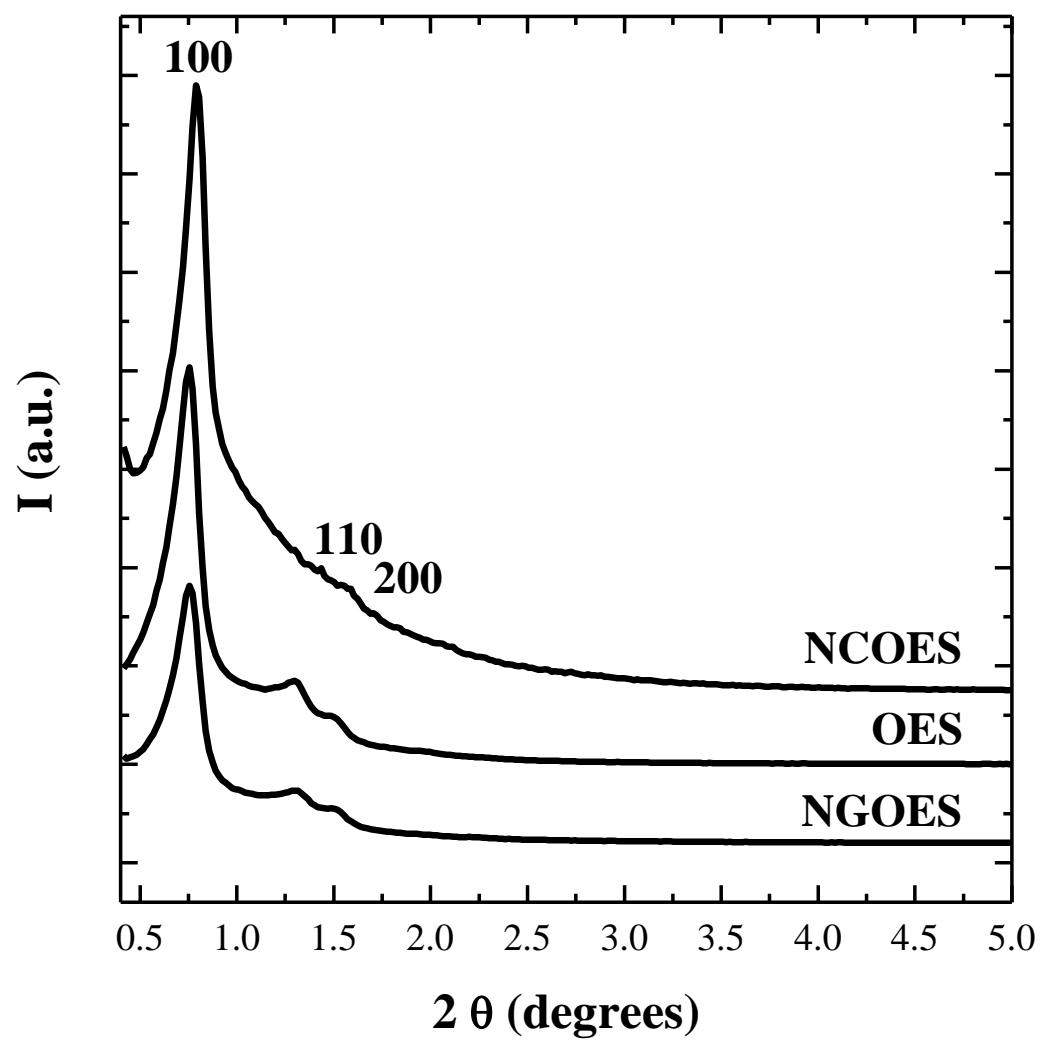




\section{Figure 2.}
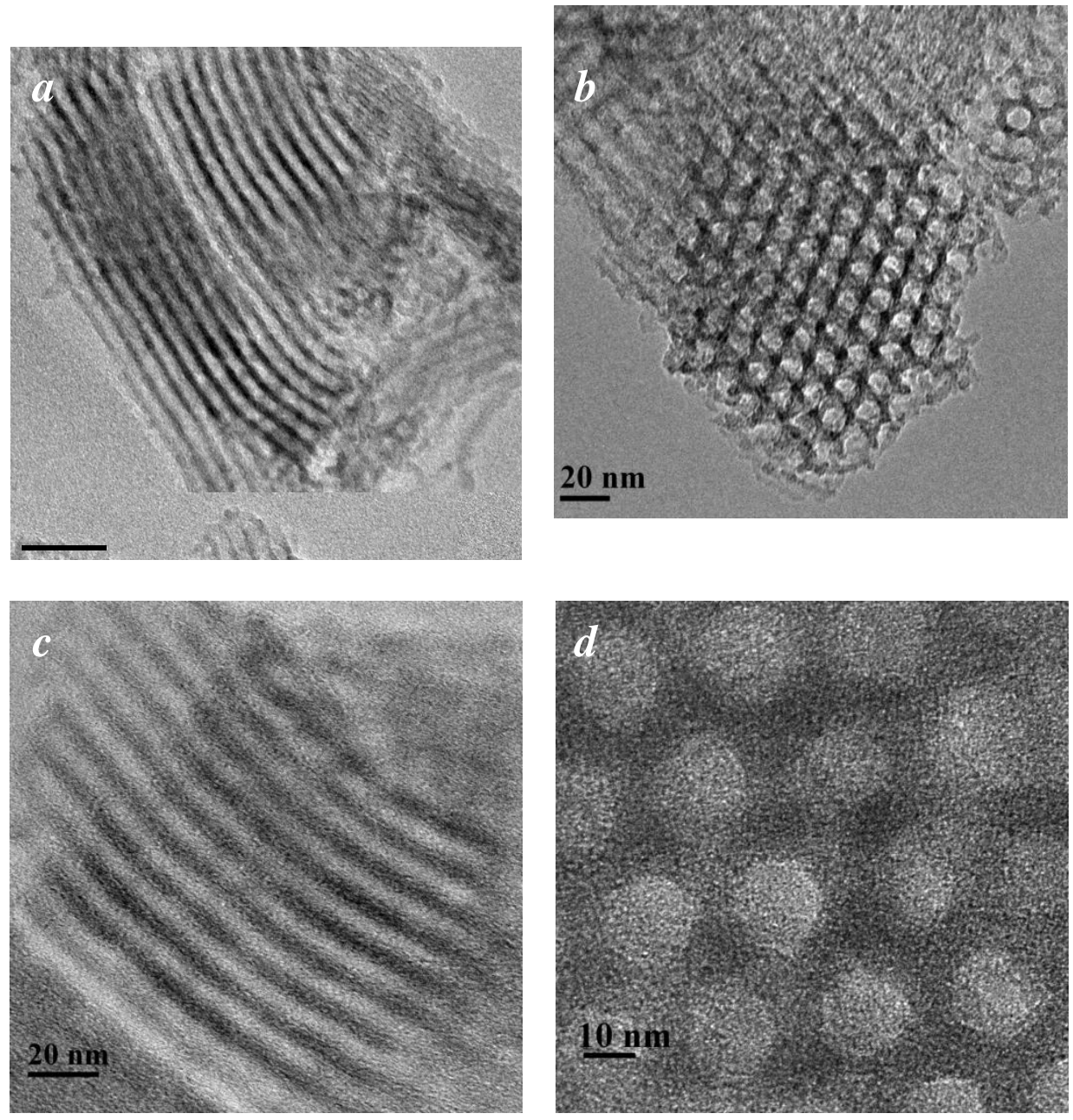
Figure 3.
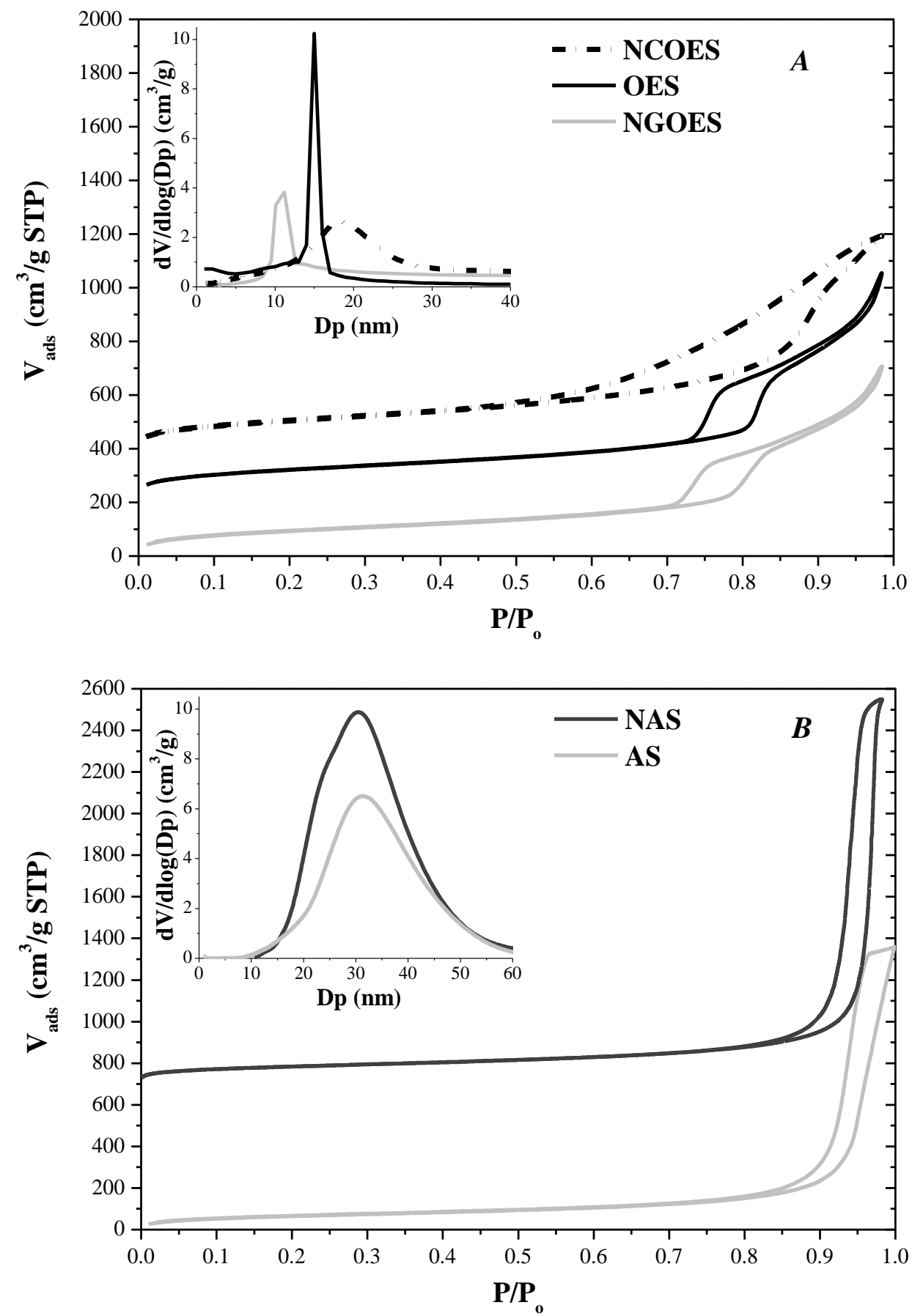
Figure 4.

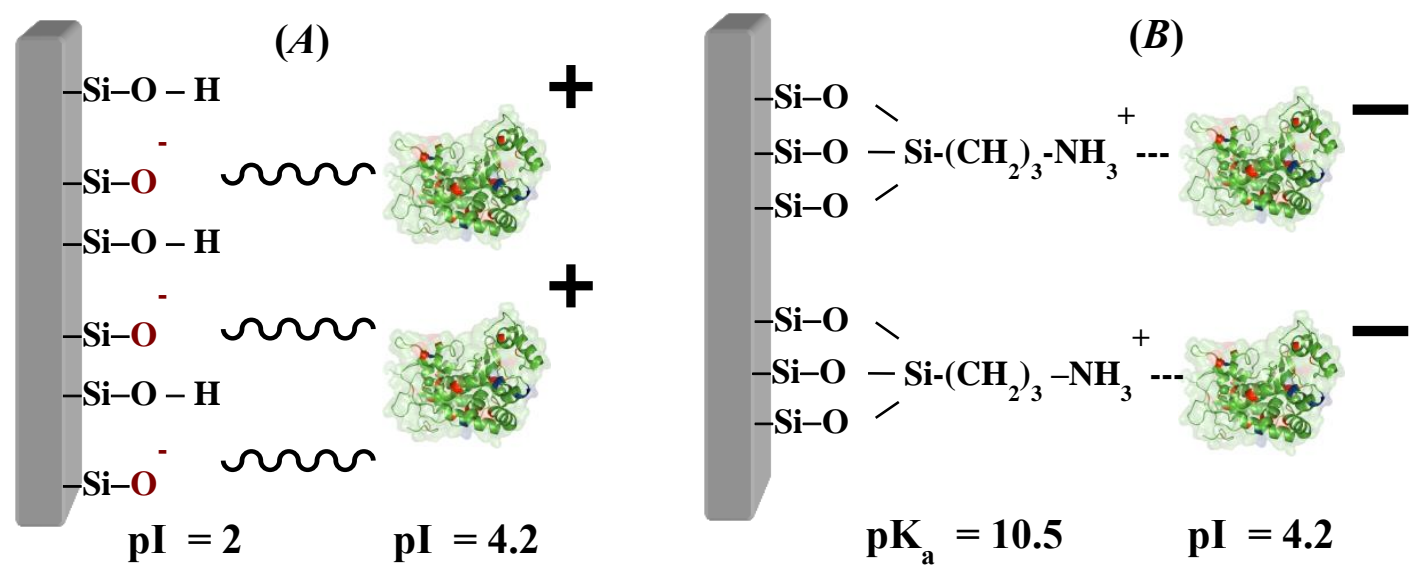


Figure 5.

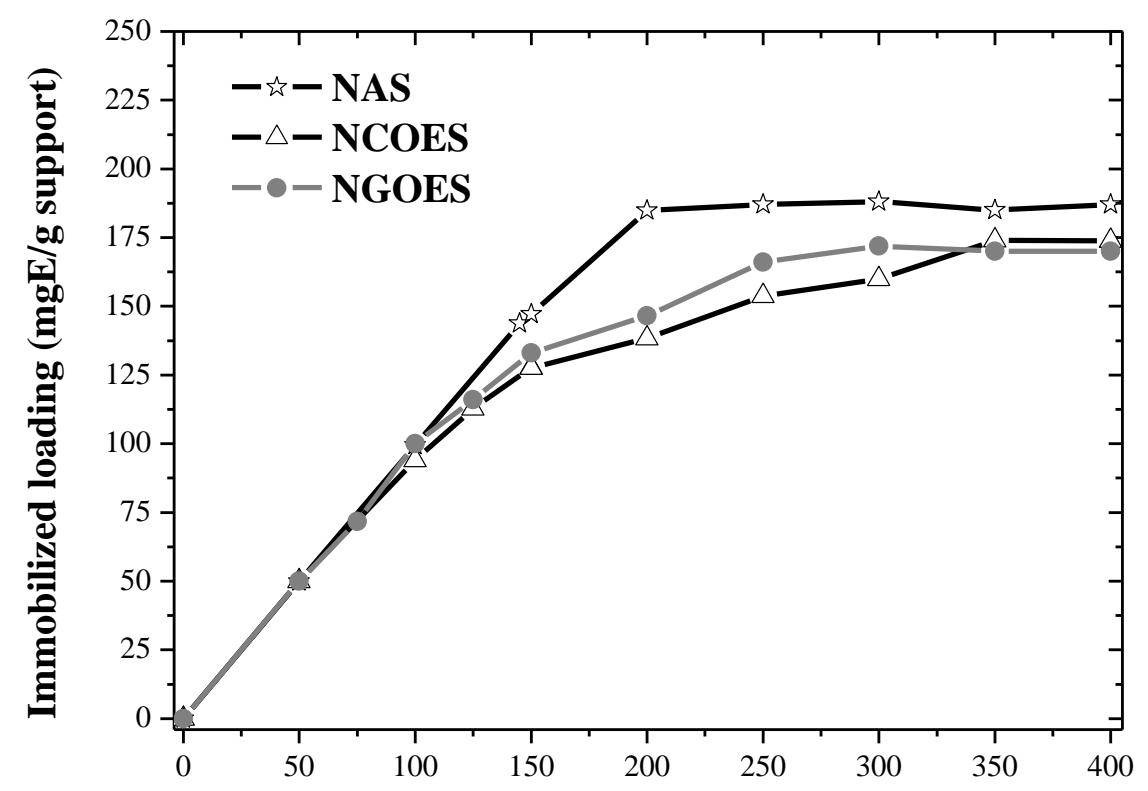

Initial amount of enzyme in solution (mgE/g support) 
Figure 6.

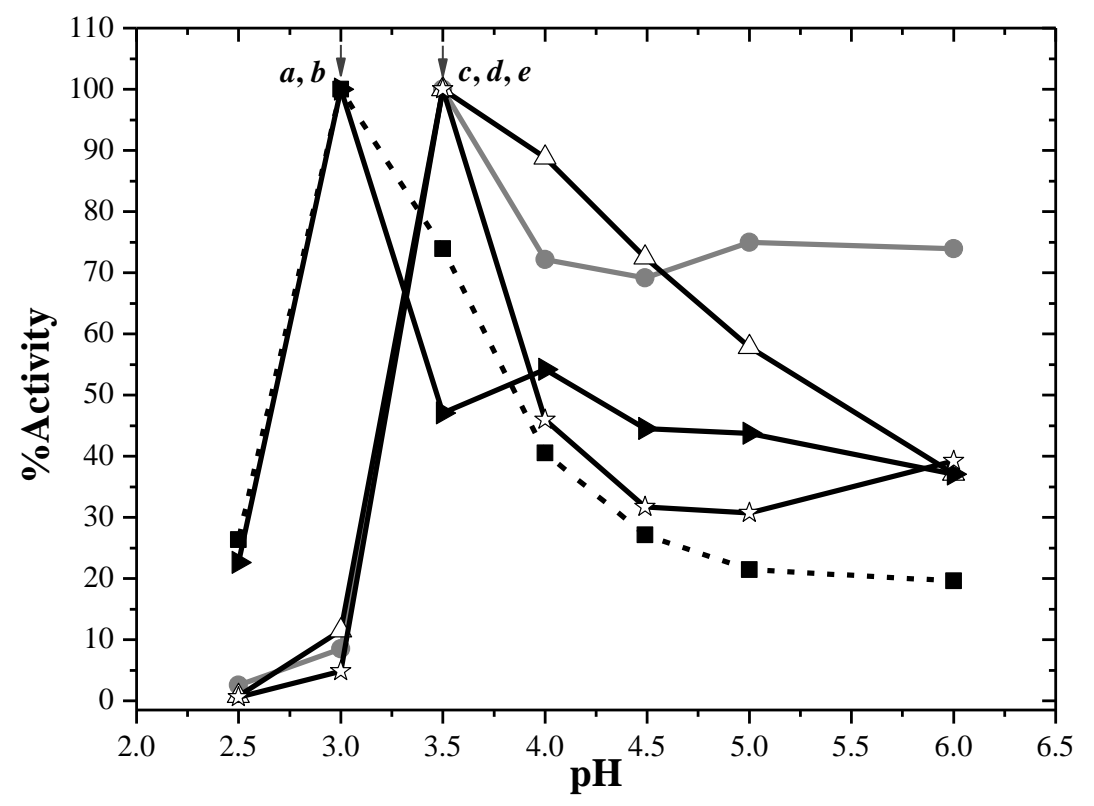


Figure 7

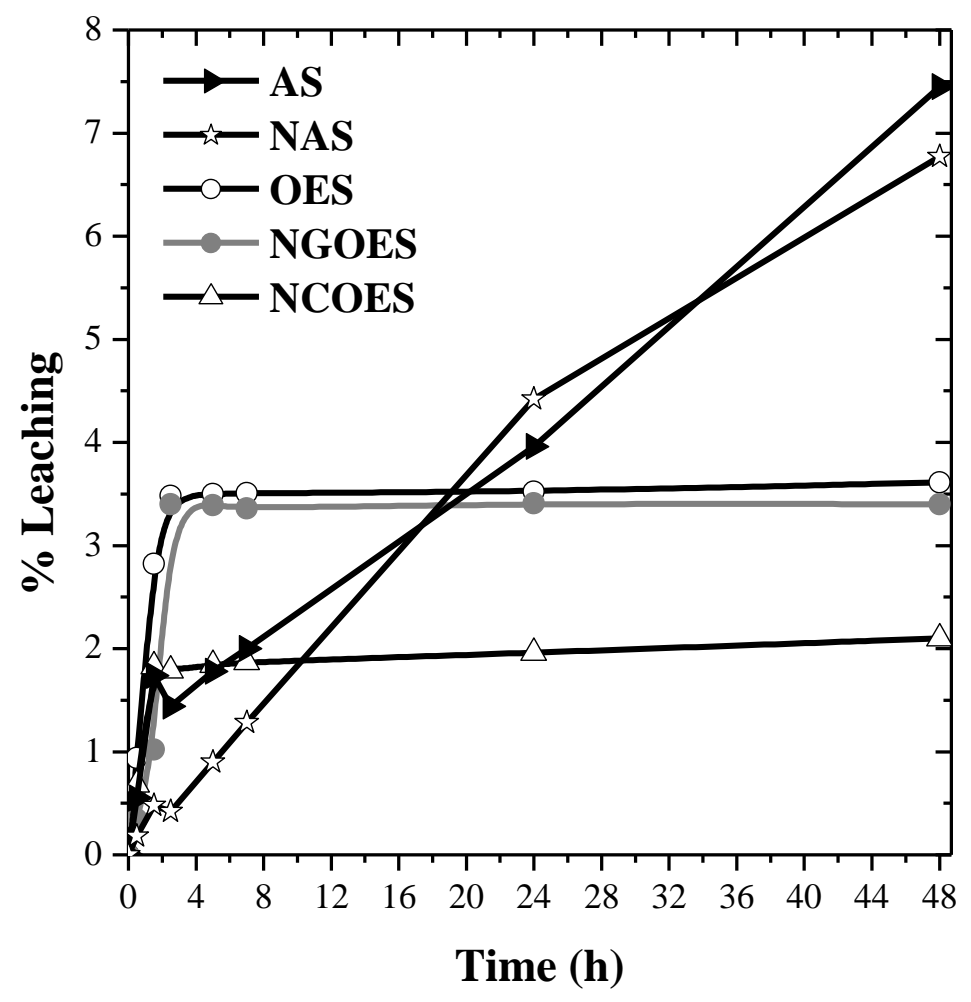


Figure 8.

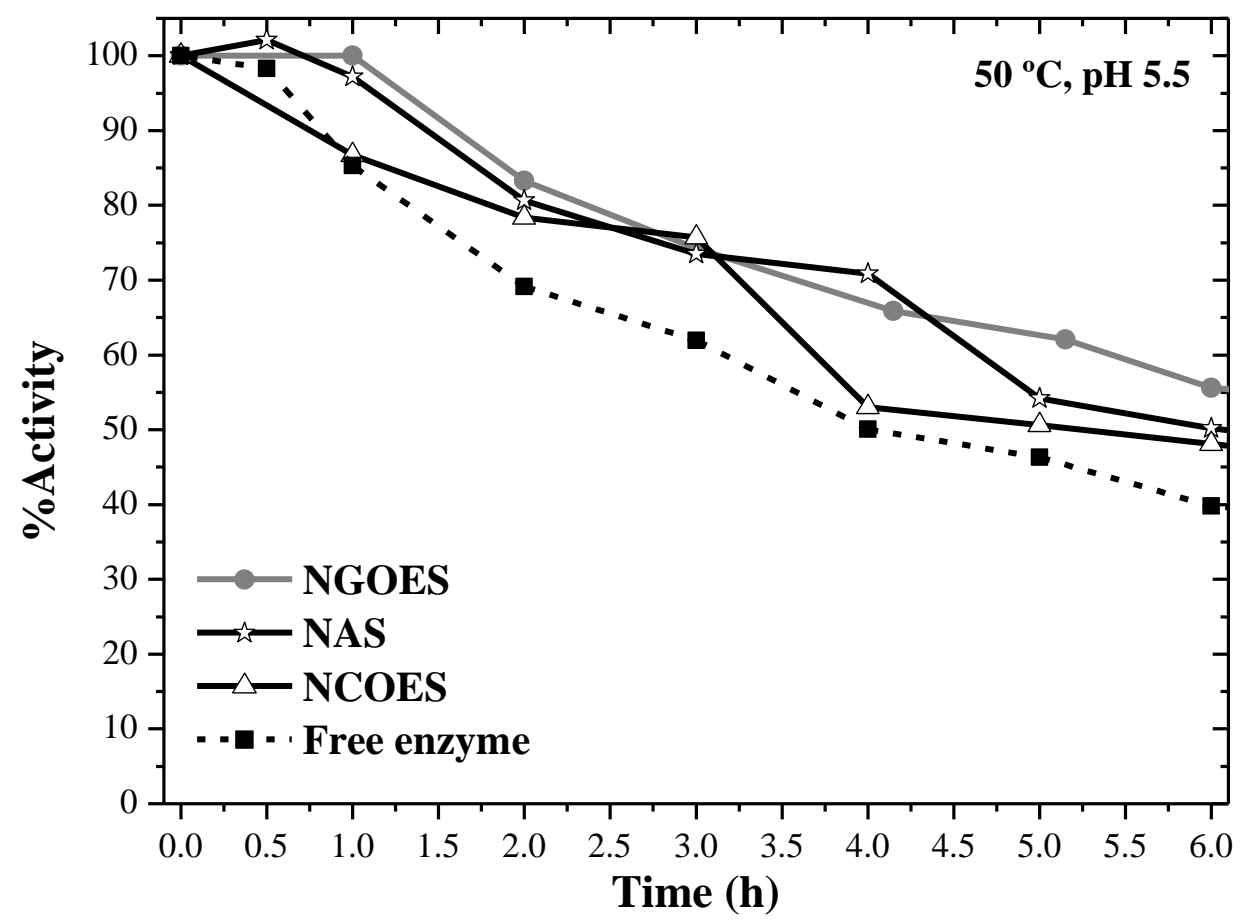


Figure 9.

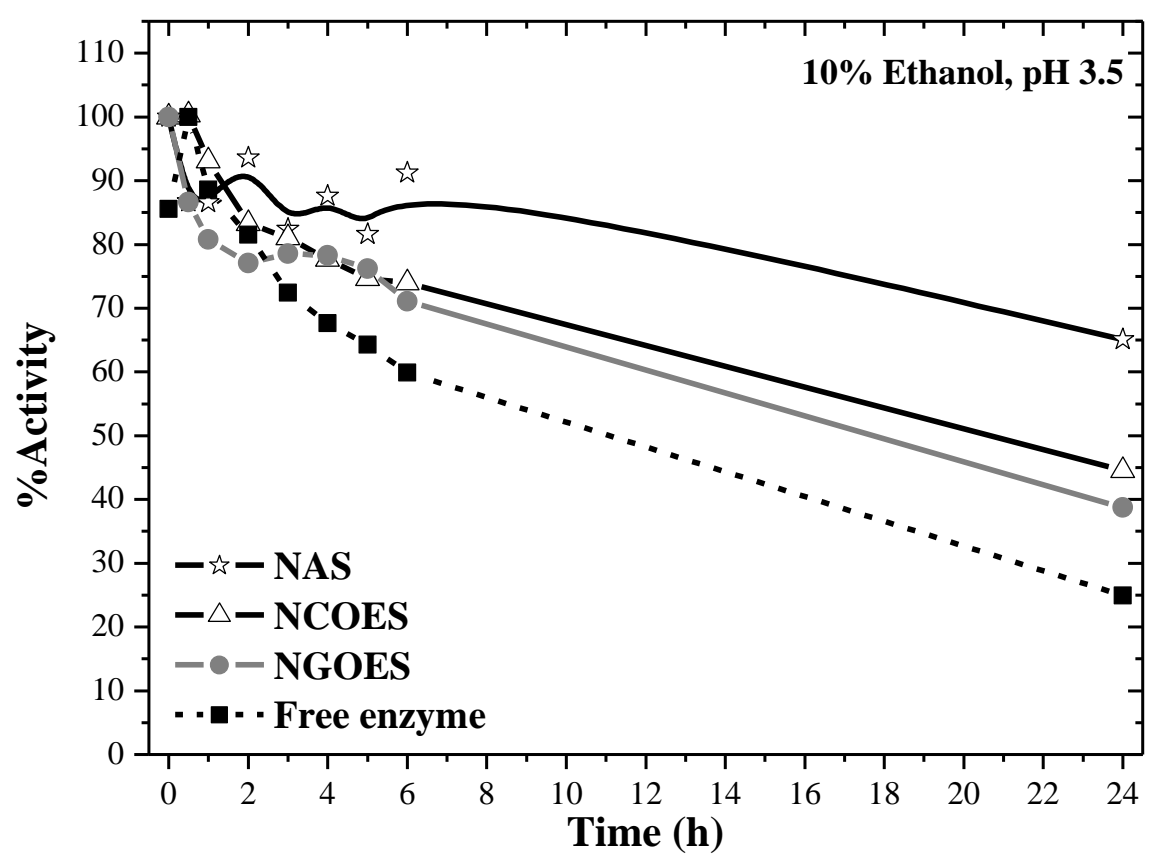



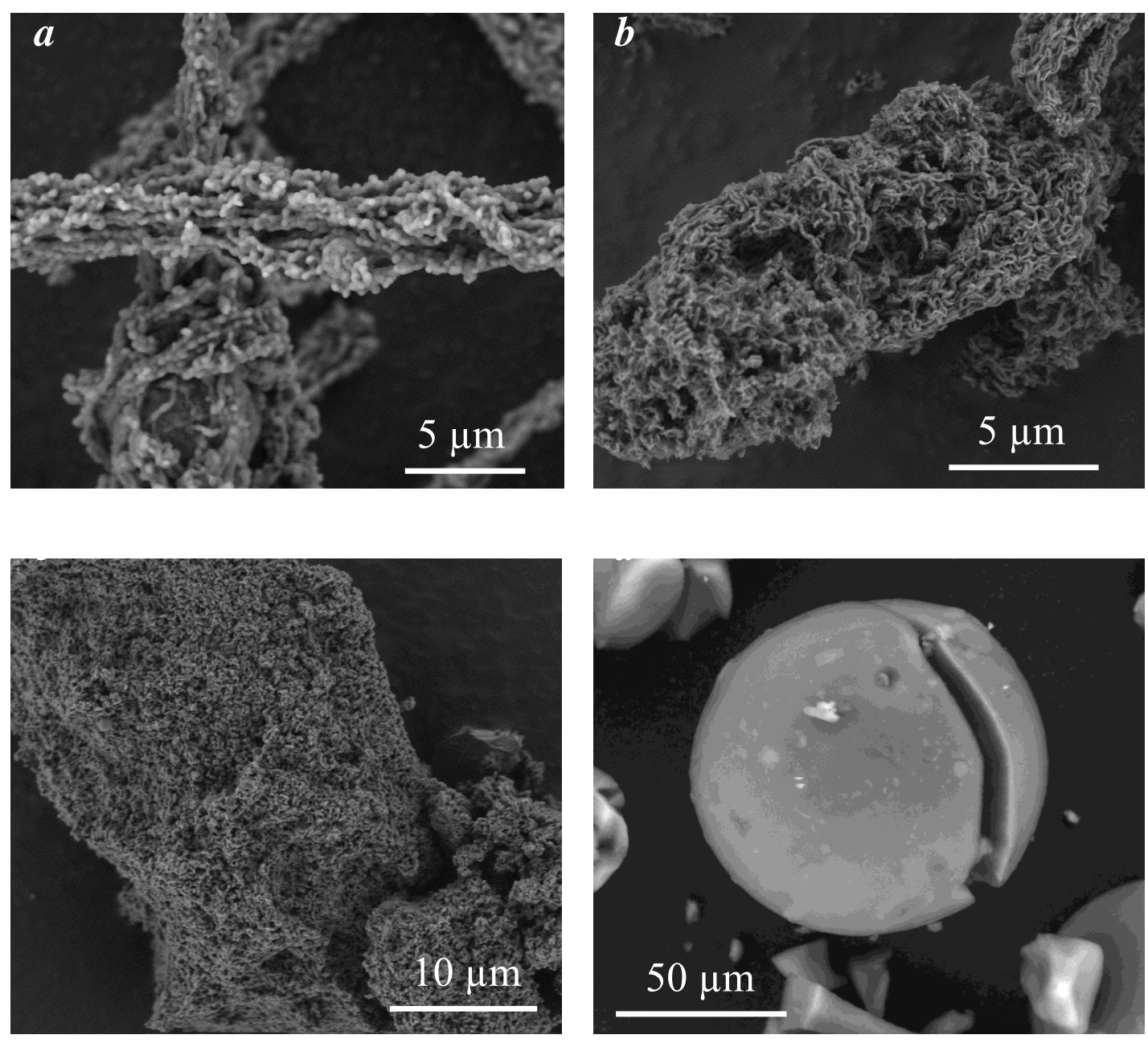

Figure S1. SEM micrograph of OES $(a)$, NGOES $(b), \operatorname{NCOES~}(c)$ and NAS $(d)$. 


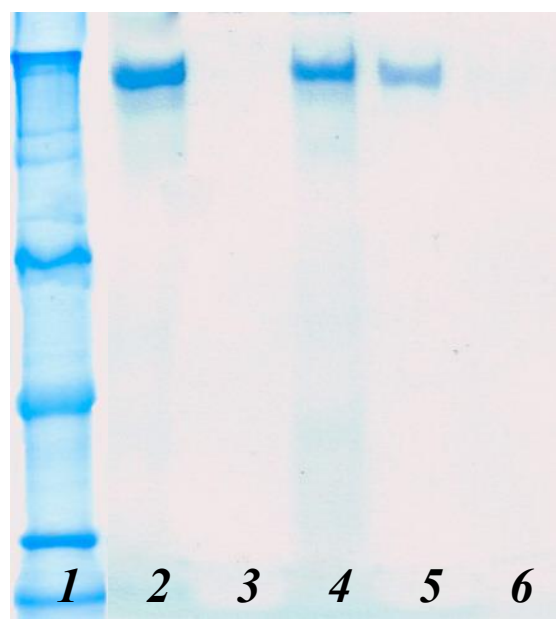

Figure S2. Electrophoresis in standard conditions. 1: Protein standard (High range SDS-Page standard stained with Coomassie G-250 stain), 2: OES, 3: NGOES, 4: AS, 5: NAS, 6: NCOES.

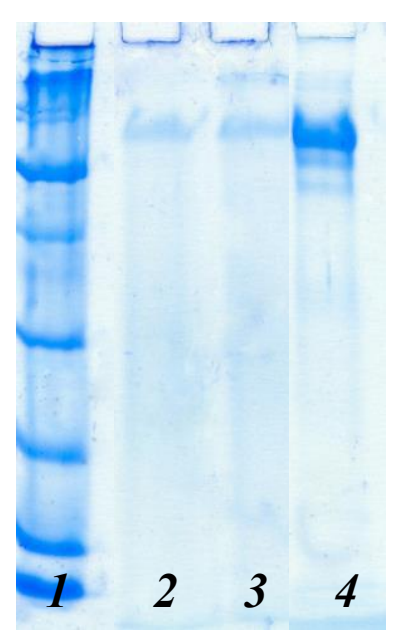

Figure S3. Electrophoresis at $\mathrm{pH}$ 11.0. 1: Protein standard; 2: NGOES, 3: NCOES, 4: Soluble laccase. 